\title{
Localization of Fibronectin in the Bovine Ovary
}

\author{
Yukinori Yoshimura, Toshikazu OKamoto \\ and Tatsudo Tamura \\ Faculty of Applied Biological Science, Hiroshima \\ University, Higashi-Hiroshima-shi 724
}

(Received October 31, 1990)

Key words : bovine ovary, fibronectin, follicular growth, atresia

The structure of the bovine ovarian follicle markedly changes as it enlarges. Granulosa cells first form a single layer around the oocyte in the primordial follicle, whereas the granulosa cells proliferate and form a multi-cellular layer in the preovulatory follicle. The theca interna and externa layers which are the supporting wall of the growing follicle also undergo developmental changes during follicular development ${ }^{11}$. Fibronectin (FN) is an important extracellular matrix which regulates the adhesion of cell-cell or cell-substrate as well as the growth and differentiation of the cells $s^{3,10}$. Since the structure of the ovarian follicle is significantly changed during follicular development, FN may play an important role in this process. It has been reported that cultured mammalian granulosa cells produce $\mathrm{FN}^{2,4,8,9}$, and that the basal lamina underlying the granulosa layer contains $\mathrm{FN}^{1}$. . However, the in situ localization of $\mathrm{FN}$ in ovarian tissues such as the follicular wall and the tissues surrounding these structures remains to be described. The purpose of this study was to localize FN in the bovine ovary by an immunohistochemical method.

\section{Materials and Methods}

Ovaries which have normal antral follicles or atretic follicles were obtained from eight cows at a local slaughterhouse (Hiroshima, Japan). The whole ovarian tissue was quickly frozen in an isopentane-dry ice mixture and cut into small pieces. Then, they were embedded in Cryo-M-Bed compound (Bright Co., Cambs., UK) and placed again into an isopentane-dry ice mixture. Unfixed cryostat sections of them were air dried on the albumin coated slides for $30 \mathrm{~min}$ at room temperature, and immunostained for FN as described by KIENY and MAUGER ${ }^{7)}$. After rehydration with phosphate buffered saline (PBS), sections were incubated with the rabbit anti-bovine $\mathrm{FN}$ antibody (UCB Bioproducts S.A., Brussels, Belgium) diluted 1: 100 with PBS for $2 \mathrm{hrs}$ in a moist chamber at room temperature. After rinsing the slides in PBS ( 3 times for $5 \mathrm{~min}$ each), sections were then incubated with FITC conjugated goat anti-rabbit $\operatorname{IgG}(\mathrm{E}-\mathrm{Y}$ Laboratories Inc., CA, USA) diluted 1:20 with PBS for $1 \mathrm{hr}$. Slides were washed in PBS and covered with glycerol-PBS. Control slides for non-specific immunostaining were identically

ウシ卵巢におけるフィブロネクチン分布：吉村幸勋・阔本敏一・田村達堂（达島大学生物生産学部 東広島市 $724 ）$

Anim. Sci. Technol. (Jpn.) 62 (6): 529-532 529 
prepared, except that the first antibody was replaced with normal rabbit serum. Sections were examined under a fluorescence microscope (Olympus BH, Tokyo, Japan).

The cross reactivity of the rabbit anti-bovine FN antibody with bovine FN was tested using immunodiffusion. Bovine plasma which is known to contain $\mathrm{FN}^{10)}$ was placed in the central well and various dilutions of the antibovine FN antibody $(1: 25$ to $1: 800)$ were placed in the outer wells. Diffusion was allowed to proceed for $24 \mathrm{hrs}$. A single precipitation line was found between plasma $\mathrm{FN}$ and the FN antibody diluted $1: 25$ to $1: 100$.

\section{Results}

In the primordial follicles, a strong FN immuno-fluorescence was found in the basal lamina underlying the granulosa cells. The basal lamina underlying the superficial epithelium as well as the collagenous bundles in the tunica albuginea and stroma were also positive for FN immunostaining (Figs. 1, 2). The follicular wall of the antral follicles consisting of the granulosa layer, theca interna and theca externa was positive for the FN immunostaining. The $\mathrm{FN}$ immunofluorescence in the externa was positive for the $\mathrm{EN}$ immunostaining. The FN immunofluorescence in the granulosa layer was also positive for FN immunostaining. In the theca interna the FN immunofluorescence showed a strand like distribution in the intercellular space, suggesting that the FN localization is associated with the collagenous fibers (Fig. 3).

In follicles undergoing the early stage of atresia, granulosa cells were separated from the follicular wall. A strong FN immunostaining was observed in the intercellular space of the granulosa cells where cells were attached to each other but not on the free surface of the cells. Clusters of FN positive substances were scattered in the follicular fluid (Fig. 4).

FN immunoreaction was absent in the cytoplasm of the granulosa cells of the primor- dial, antral and atretic follicles (Figs. 1, 3, 4). No fluorescence was observed in the control sections suggesting that the fluorescence in the experimental sections specifically indicated the presence of $\mathrm{FN}$.

\section{Discussion}

The main findings of this study are that in the bovine ovary FN is located 1) on the surface of the granulosa cells, 2) in the basal lamina underlying the granulosa layer and superficial epithelium and 3) in the connective tissue of the theca layer, stroma and tunica albuginea.

It has been established that FN is implicated in cell growth as well as cell-cell and cellsubstratum adhesion ${ }^{3,10)}$. Previous studies have shown that mammalian granulosa cells produce FN in culture $2,4,8,9)$. These authors indicated that the secretion of $\mathrm{FN}$ by granulosa cells was suppressed by FSH and CAMP at a time when granulosa cells were differentiating as assessed by an increase in aromatase activity ${ }^{8,9)}$. FSH which stimulates follicular growth induces the cytodifferentiation of the granulosa cells via $\mathrm{cAMP}^{6)}$. Therefore, these authors proposed that this FSH decrease of FN secretion by the granulosa cells was related to the granulosa cell cytodifferentiation. In the present study, it is not possible to describe the changes of the activity of FN secretion in the granulosa cells during follicular growth. However, it was clearly demonstrated that FN was distributed on the surface of the actively proliferating granulosa cells of normal growing follicles. On the other hand, in the atretic follicles in which the granulosa cells were separating from each other, FN was localized only in the intercellular space of the granulosa cells where they were attached to adjacent cells but not on the free surfaces of the granulosa cells. These findings suggest that the presence of $\mathrm{FN}$ on the surface of granulosa cells is essential for the adhesion and proliferation of the granulosa cells during the follicular growth. 

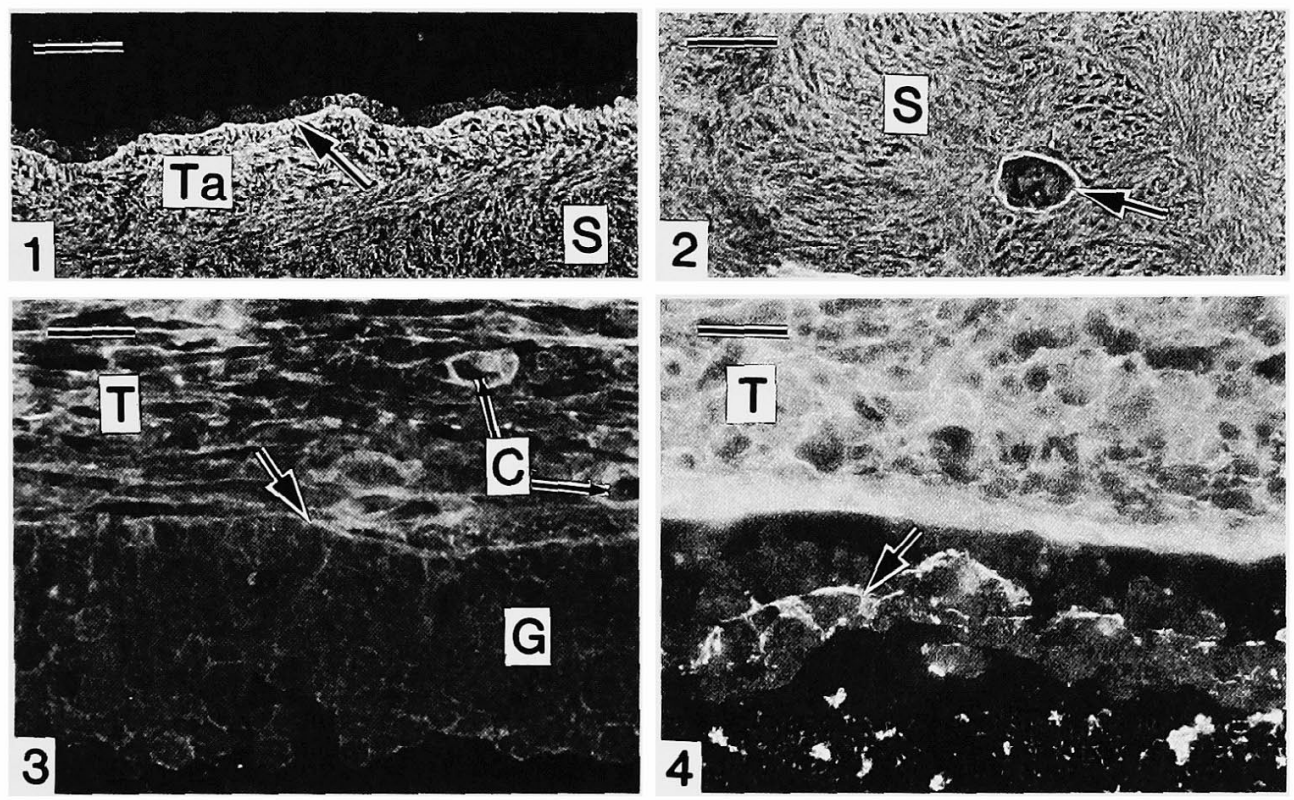

Fig. 1. Section of the ovarian surface tissues immunostained for fibronectin. The basal lamina underlying the surface epithelium (arrow) as well as the connective tissues including the tunica albuginea ( $\mathrm{Ta}$ ) and stroma (S) are positive for fibronectin immunostaining. Scale bar $=50 \mu \mathrm{m}$. (original magnification $=\times 200$ ).

Fig. 2. Section of a primordial follicle immunostained for fibronectin. Note the strong fluorescence in the basal lamina underlaying the granulosa layer of the primordial follicle (arrow). S: stroma. Scale bar $=50 \mu \mathrm{m}$.

(original magnification $=\times 200)$.

Fig. 3. Section of the wall of an antral follicle immunostained for fibronectin. Note the immunostaining for fibronectin on the surface of the granulosa cells (G), basal lamina (arrow) and the intercellular space of the theca interna ( $T$ ). C : capillary vessel. Scale bar $=25 \mu \mathrm{m}$. (original magnification $=\times 400$ ).

Fig. 4. Section of the wall of atretic follicle immunostained for fibronectin. Note that the intercellular space among the attached granulosa cells is strongly positive for the immunoreaction (arrow) but the free surface of the granulosa cells is negative. $\mathrm{T}$ : theca interna. Scale bar $=25 \mu \mathrm{m}$. (original magnification $=\times 400$ ).

Immunostaining for $\mathrm{FN}$ was observed not in the cytoplasm of the granulosa cells but on their surface. It may be possible that $\mathrm{FN}$ is produced by the granulosa cells but the amount of FN in their cytoplasm is not enough to be detected by the present method. It is considered that FN secreted by the granulosa cells is accumulated on their surface.

In the atretic follicles, FN positive substances were scattered in the follicular fluid.
Although the physiological significance of these substances is unknown, a previous publication by DoRrington and SkINNER ${ }^{4)}$ offers an interpretation. They showed that FSH promoted a state of cytodifferentiation of the granulosa cells which produced low levels of FN and high levels of steroid hormones typical of normal follicles. In contrast, GnRH promoted a state of cytodifferentiation of granulosa cells in which there was a high level of FN 
production and a low level of steroidogenesis. On the basis of these results, DORRINGTon and SKINNER ${ }^{4)}$ suggested that FN secretion might be high in the atretic follicle and/or corpus luteum.

The major matrix components of a basal lamina in various tissues are $\mathrm{FN}$ and laminin ${ }^{10}$. The present results indicated that the basal lamina underlying the granulosa layer of normal growing follicles and the superficial epithelium also contained FN. This result supports the report of BAGAviandoes et al. ${ }^{11}$ who found that basal lamina underlying the granulosa layer contains $F N$ in rats. They also showed that the $\mathrm{FN}$ in the basal lamina was disintegrated in the follicles undergoing atresia as well as just prior to ovulation.

The theca interna and externa contained FN. It is generally accepted that $F N$ is an important adhesive factor in the connective tissues. Since the thecal layer is the connective tissue supporting the follicles, the adhesive effect of FN in the theca may be important to maintain the structure of the growing follicles. Our previous study in the chicken indicated that $\mathrm{FN}$ in the theca was reduced when the follicle ovulated or the follicle became atretic $^{11}$.

In conclusion, it was found that in the bovine ovary FN is located in the granulosa layer, basal lamina, thecal layer and the other connective tissues. It is suggested that FN plays an important role for the adhesion and proliferation of the granulosa cells in the growing follicles.

\section{Acknowlegements}

We are indebted to Dr. JANICE M. BAHR, University of Illinois for her critical review of this manuscript.

\section{References}

1) Bagavandoss, P., Midgley, A.R. Jr. and
WichA, M., Developmental changes in the ovarian follicular basal lamina detected by immunofuorescence and electron microscopy. J. Histochem. Cytochem., 31: 633-640. 1983

2) Carnegie, J.A., Secretion of fibronectin by rat granulosa cells occurs primarily during early follicular development. J. Reprod. Fert., 89: 579-589. 1990.

3) Cidadao, A.J., Thorsteinsdottir, S. and DAVID-FERREIRA, J.F., Reevaluation of fibronectin-collagen interactions in tissues: an immunocytochemical and immunochemical study. J. Histochem. Cytochem., $36: 639-648$. 1988.

4) Dorrington, J.H. and SKInNer, M.K., Cytodifferentiation of granulosa cells induced by gonadotropin releasing hormone promotes fibronectin secretion. Endocrinology, 118 : 2065-2071. 1986.

5) HAFE2, E.S.E., Functional anatomy of reproduction. in Reproduction in Farm Animals (HAFEZ, E.S.E. ed.) 7-82. Lea and Febiger. Philadelphia. 1980.

6) Hsuer, A.J.W., Adashi, E.Y., Jones, P.B.C. and WeLSH, T.H., Hormonal regulation of differentiation of cultured ovarian granulosa cells. Endoc. Rev., 5: 76-127. 1985.

7) Kieny, M. and Mavger, A., Immunofluorescent localization of extracellular matrix componerits during muscle morphogenesis. 1. In normal chick embryos. J. exp. Zool. 232 : 327-341. 1984.

8) Skinner, M.K. and DoRRington, J.H., Control of fibronectin synthesis by rat granulosa cells in culture. Endocrinology, 115 : 2029-2031. 1984.

9) Skinner, M.K., MCKeracher, H.L. and DORRINGTON, J.H., Fibronectin as a marker of granulosa cell cytodifferentiation. Endocrinology, 117 : 886-892. 1985.

10) YamadA, K.M., Cellular surface interactions with extra-cellular materials. Ann. Rev. Biochem., 52 : 761-799. 1983.

11) Yoshimura, Y., Okamoto, T. and Tamura, $\mathrm{T}$, Immuno-histochemical observations on the distribution of fibronectin in hen's ovarian follicles. Jpn. Poult. Sci., 22 : 274278. 1985. 